\title{
The walls of Carthage and the date of Augustine's De Trinitate
}

Accepted for Journal of Theological Studies (17/11/2018), forthcoming either 2019 or 2020.

Andrew Wilson

University of Oxford

andrew.wilson@arch.ox.ac.uk

\section{Abstract}

This article calls attention to a hitherto overlooked piece of evidence that securely dates the completion of Book IX and subsequent books of Augustine's De Trinitate to AD 424/425 or later: in it Augustine refers to having seen the moenia (defensive walls) of Carthage, which were not built until AD 424/425. The paper reviews the evidence for and previous scholarship on the chronology of the composition and completion of the De Trinitate, and considers the implications of the new dating for the circumstances of its completion, situating it within the production of his other major works in the mid-late 420 s.

Augustine's work on the Trinity was a long time in the making; but precisely how long, and when it was eventually published, have been debated for more than a century. Estimates for when he started the De Trinitate range between AD 397 and 404, while most guesses for its completion range from 417 to $421 / 422$. The question has some significance both for the evolution of Augustine's thought as he wrote, and the extent to which the completion and publication of the work may have been prompted by particular events such as the condemnation of Pelagianism at the Council of Carthage in $418 .{ }^{1}$ It is the purpose of this article to call attention to a piece of evidence, so far overlooked, that securely places the date of completion between AD 424/5 and 427: Augustine says that he has seen the walls of Carthage, and these

\footnotetext{
${ }^{1}$ Jean Plagnieux, 'L'influence de la lutte antipélagienne sur le De Trinitate ou: Christocentrisme de saint Augustin', in, Augustinus Magister. Congrès international augustinien, Paris, 21-24 septembre 1954 (Augustinus Magister. Congrès international augustinien, Paris, 21-24 septembre 1954, 1954), pp. 817-26.
} 
defences were not built before 424 or 425 . Further arguments following from this terminus post quem suggest that the most probable date for the completion of the De Trinitate is 426 or 427.

\section{The evidence of Augustine's own writings}

Augustine himself tells us, in the dedicatory epistle to Bishop Aurelius of Carthage (Ep. 174) that accompanied the work's eventual publication, that he begun the De Trinitate as a young man and published it in his old age: de trinitate, quae deus summus et uerus est, libros iuuenis inchoaui, senex edidi. Both in this letter and in the Retractationes he explains how the incomplete work began circulating, in an unauthorised version, before the twelfth book (of the eventual fifteen) had been completed. It was this circumstance that forced Augustine to complete it at the request of friends and colleagues (fratres):

I spent some years in writing fifteen books concerning the Trinity, which is God. When, however, I had not yet finished the twelfth Book, and some who were exceedingly anxious to have the work were kept waiting longer than they could bear, it was stolen from me in a less correct state than it either could or would have been had it appeared when I intended. And as soon as I discovered this, having other copies of it, I had determined at first not to publish it myself, but to mention what had happened in the matter in some other work; but at the urgent request of brethren, whom I could not refuse, I corrected it as much as I thought fit, and finished and published it, with the addition, at the beginning, of a letter that I had written to the venerable Aurelius, Bishop of Carthage, in which I set forth, in the way of prologue, what had happened, what I had intended to do of myself, and what love of my brethren had forced me to do. ${ }^{2}$

The letter to bishop Aurelius which accompanied the completed work, and which Augustine requested be prefaced to the books of the early draft that some people already had, gives a fuller account (Ep. 174):

\footnotetext{
${ }^{2}$ Retractationes (II.15), trans. Haddan (1873, pp. vii-viii), with the correction of 'thirteenth book' to 'twelfth book'. CCSL 57, p. 101: Libros de trinitate, quae deus est, quindecim scripsi per aliquot annos. sed cum eorum duodecim non perfecissem et eos diutius tenerem, quam posset sustinere, qui uehementer eos habere cupiebant, subtracti mihi sunt mihi minus emendati, quam deberent ac possent, quando eos edere uoluissem. quod posteaquam conperi, quia et alia eorum apud nos exemplaria remanserant, statueram eos iam ipse non edere, sed sic habere, ut alio aliquo opusculo meo, quid mihi de his euenerit, dicerem. urguentibus tamen fratribus quia resistere non eis ualui - emendaui eos, quantum emendandos putaui, et conpleui et edidi adiungens eis a capite epistulam, quam scripsi ad uenerabilem Aurelium, episcopum Carthaginiensis ecclesiae, quo tamquam prologo exposui et quid accidisset et quid facere mea cogitatione uoluissem et quid fratrum conpellente caritate fecissem.
} 
To the most blessed Lord, whom he reveres with most sincere love, to his holy brother and fellow-priest, Pope Aurelius, Augustine sends health in the Lord.

I began as a very young man, and have published in my old age, some books concerning the Trinity, who is the supreme and true God. I had in truth laid the work aside, upon discovering that it had been prematurely, or rather surreptitiously, stolen from me before I had completed it, and before I had revised and put the finishing touches to it, as had been my intention. For I had not designed to publish the Books one by one, but all together, inasmuch as the progress of the inquiry led me to add the later ones to those which precede them. When, therefore, these people had hindered the fulfillment of my purpose (in that some of them had obtained access to the work before I intended), I had given over dictating it, with the idea of making my complaint public in some other work that I might write, in order that whoso could might know that the Books had not been published by myself, but had been taken away from my possession before they were in my own judgment fit for publication. Compelled, however, by the eager demands of many of my brethren, and above all by your command, I have taken the pains, by God's help, to complete the work, laborious as it is; and as now corrected (not as I wished, but as I could, lest the Books should differ very widely from those which had surreptitiously got into people's hands), I have sent them to your Reverence by my very dear son and fellow-deacon, and have allowed them to be heard, copied, and read by every one that pleases. Doubtless, if I could have fulfilled my original intention, although they would have contained the same sentiments, they would have been worked out much more thoroughly and clearly, so far as the difficulty of unfolding so profound a subject, and so far, too, as my own powers, might have allowed. There are some persons, however, who have the first four, or rather five, Books without the prefaces, and the twelfth with no small part of its later chapters omitted. But these, if they please and can, will amend the whole, if they become acquainted with the present edition. At any rate, I have to request that you will order this letter to be prefixed separately, but at the beginning of the Books. Farewell. Pray for me. ${ }^{3}$

\footnotetext{
${ }^{3}$ Ep. 174, trans. Haddan (1873, p. viii-ix). CSEL 44, p. 650-1: Domino beatissimo et sincerissima caritate uenerando sancto fratri et consacerdoti papae Aurelio Augustinus in domino salutem.

De trinitate, quae deus summus et uerus est, libros iunenis inchoaui, senex edidi. omiseram quippe hoc opus, posteaquam comperi praereptos mihi esse siue subreptos, antequam eos absoluerem et retractatos, ut mea dispositio fuerat, expolirem. non enim singillatim sed omnes simul edere ea ratione decreueram, quoniam praecedentibus consequentes inquisitione proficiente nectuntur. cum ergo per eos homines, qui, priusquam
} 
Augustine must have started the De Trinitate in the very early 400s if not before: he had certainly begun it by the time he prepared his reply to a letter from the Donatist bishop Petilianus in $401 .^{4}$ In spring AD 412 friends were already pressing him to complete the work and publish it (Ad Marcellinum, Ep. 143); ${ }^{5}$ but further letters in 414 and 415 show that it was

uellem, ad quosdam illorum peruenire potuerunt, dispositio mea nequiuisset impleri, interruptam dictationem reliqueram cogitans hoc ipsum in aliquibus scriptis meis conqueri, ut scirent, qui possent, non a me fuisse eosdem libros editos sed ablatos, priusquam mihi editione mea digni uiderentur. uerum multorum fratrum uehementissima postulatione et maxime tua iussione compulsus opus tam laboriosum adiunante domino terminare curaui eos que emendatos, non ut uolui, sed ut potui, ne ab illis, qui subrepti iam in manus hominum exierant, plurimum discreparent, uenerationi tuae per filium nostrum condiaconum carissimum misi et cuicumque audiendos, legendos describendos que permisi. in quibus si seruari mea dispositio potuisset, essent profecto etsi easdem sententias habentes multo tamen enodatiores atque planiores, quantum rerum tantarum explicandarum difficultas et facultas nostra pateretur. sunt autem, qui primos quattuor uel potius quinque etiam sine prooemiis habent et duodecimum sine extrema parte non parua. sed si eis haec editio potuerit innotescere, omnia, si uoluerint et ualuerint, emendabunt. peto sane, ut hanc epistulam seorsum quidem sed tamen ad caput eorundem librorum iubeas anteponi. ora pro me.

${ }^{4}$ Ephraem Hendrikx, 'Notes complémentaires', in M. Mellett, Th. Camelot, and E. Hendrickx (eds), La Trinité (Livres I-VII). 1. Le Mystère (La Trinité (Livres I-VII). 1. Le Mystère, 15; Paris: Desclée De Brouwer, 1955), pp. 557-91, p. 562. Retractationes II.25 (CCSL 57 p. 110): antequam finirem libros de trinitate et libros de Genesi ad litteram, inruit causa respondendi litteras Petiliani Donatistae quas aduersas Catholicam scripsit, quam differre non potui. 'Before I had finished the books on The Trinity and the books on The Literal Interpretation of Genesis, there arose the issue of responding to the letters of Petilianus the Donatist, which he wrote against the Catholics, which I could not put off.'

${ }^{5}$ Ep. 143.4. CSEL 44, pp. 253-4: cum ergo non, sicut quidam carissimi mei putant, nulla uel pauca sed potius plura fortasse, quam etiam maledici opinantur, uerba dixerim, quae mallem reuocare, si possem, non mihi Tulliana illa blanditur, qua dictum est: 'nullum umquam uerbum, quod reuocare uellet, emisit', sed angit me plane Horatiana sententia: 'nescit uox missa reuerti'. hinc est, quod periculosissimarum quaestionum libros de genesi scilicet et de trinitate diutius teneo, quam uultis et fertis, ut, si non potuerint nisi habere aliqua, quae merito reprehendantur, saltem pauciora sint, quam esse possent, si praecipiti festinatione inconsultius ederentur. uos enim, ut uestrae indicant litterae —nam hoc mihi sanctus frater et coepiscopus meus scripsit Florentius-, ideo, ut edantur. urgetis, quo possint a me, dum in hac carne uiuo, defendi. cum uel ab inimicis mordentibus uel etiam ab amicis parum intellegentibus fortasse in quibusdam coeperint accusari. quod utique propterea dicitis, quia non putatis esse in aliquid, quod uera possit ratione culpari; alioquin non me ad eorum editionem sed ad diligentiorem emendationem potius hortaremini. ego autem iudices ueros et ueritate seueros magis intueor, inter quos et me ipsum primitus constituere uolo, ut ad illos ea tantum reprehendenda perueniant, quae a me quamuis sedulo perscrutante uideri minime potuerint.

'Since, therefore, the words spoken by me which I would if I could recall, are not, as my very dear friends suppose, few or none, but perhaps even more than my enemies imagine, I am not gratified by such commendation as Cicero's sentence, "He never uttered a word which he would wish to recall," but I am deeply distressed by the saying of Horace, "The word once uttered cannot be recalled." This is the reason why I keep beside me, longer than you wish or patiently bear, the books which I have written on difficult and important questions on the book of Genesis and the doctrine of the Trinity, hoping that, if it be impossible to avoid having some things which may deservedly be found fault with, the number of these may at least be smaller than it might have been, if, through impatient haste, the works had been published without due deliberation; for you, as your letters indicate (our holy brother and co-bishop Florentius having written me to this effect), are urgent for the publication of these works now, in order that they may be defended in my own lifetime by myself, when, perhaps, they may begin to be assailed in some particulars, either through the cavilling of enemies or the misapprehensions of friends. You say this doubtless because you think there is nothing in them which might with justice be censured, otherwise you would not exhort me to publish the books, but rather to revise them more carefully. But I fix my eye rather on those who are true judges, sternly impartial, between whom and myself I wish, in the first place, to make sure of my ground, so that the only faults coming to be censured by them may be those which it was impossible for me to observe, though using the most diligent scrutiny.' Trans. J. G. Cunningham, in Philip Schaff, J. G. Pilkington, and J. G. Cunningham, The Confessions and Letters of St. Augustin, with a Sketch of his Life and Work (Select library of the Nicene and post-Nicene fathers of the Christian church, First series, 1; Buffalo: Christian Literature Co., 1886). 
still unpublished then and that Augustine had more urgent priorities than continuing to work on it. Ep. 162, Ad Evodium (written in AD 414 or 415), says that many of the questions Evodius asks are answered 'in the books I have not published, either The Trinity or Genesis'; ${ }^{6}$ and Ep. 169 (AD 415) complains that Evodius's questions are preventing him from continuing work on the City of God, and that he is also being called upon for commentaries on the Psalms:

From these studies I am unwilling to be called away and hindered by any questions thrusting themselves upon me from another quarter; indeed, so unwilling, that I do not wish to turn at present even to the books on the Trinity, which I have long had on hand and have not yet completed, because they require a great amount of labour, and I believe that they can only be understood only by few. Therefore those which I hope will be useful to very many are more pressing. ${ }^{7}$

Ep. 120, Ad Consentium, is also relevant to the question: in it, Augustine answers some of Consentius' enquiries in Ep. 119 about the nature of God and the Trinity, and expresses the wish that Consentius would come and visit him so that he can read some of Augustine's works in his presence and discuss them with him face to face. He then discusses the question of the Trinity, and resumes: 'I want in the meanwhile for you to read those many things that we have already written pertinent to this question as well as those that we are still working on and cannot yet resolve on account of the magnitude of so great a question. ${ }^{8}$ This is clearly a reference to the De Trinitate, and suggests that he was turning his attention to it again. Traditionally Ep. 120 was dated to AD 410, but Hombert convincingly redates it to 414/415; and it presumably therefore belongs a little after Ep. 162 and 169, perhaps when enquiries from both Evodius and Consentius about the Trinity had prompted Augustine to think about the work again. ${ }^{9}$ Ep. $173 \mathrm{~A}$, not closely dated, also refers to working on it: 'If you think this too little, wait to read the books

\footnotetext{
${ }^{6}$ Trans. John E. Rotelle, Epistulae II: Letters 156-210 (The Works of Saint Augustine: A Translation for the 21st Century; Hyde Park, N.Y.: New City Press, 2004). CSEL 44, p. 513: iam etiam ex iis quaestionibus, quas modo misisti, multa soluta sunt in eis libris, quos nondum edidi, siue de trinitate siue de Genesi.

${ }^{7}$ Ep. 169.1.1, trans. modified after J. G. Cunningham, in Schaff, Pilkington, and Cunningham, The Confessions and Letters of St. Augustin, with a Sketch of his Life and Work. CSEL 44, p. 612: ab his me reuocari et retardari inruentibus de transuerso quibuslibet quaestionibus nolo, ita ut nec libros de Trinitate, quos diu in manibus uerso nondum compleui, modo attendere uelim, quoniam nimis operosi sunt et a pauci eos intellegi posse arbitror. unde magis urgent, quae pluribus utilia fore speramus.

${ }^{8}$ Ep. 120.13, trans. Ramsey. CCSL 31B, p. 153: interim uolo, ut legas ea, quae ad istam quaestionem pertinentia iam multa conscripsimus, illa etiam, quae in manibis habemus et propter magnitudinem tam difficilis quaestionis nondum possumus explicare.

9 Pierre-Marie Hombert, Nouvelles recherches de chronologie augustinienne (Collection des Études Augustiniennes. Série Antiquité, 163; Paris: Institut d’Études Augustiniennes, 2000), pp. 47-8.
} 
on the Trinity, which in the name of the Lord I am now disposed to publish, in the hope that they will persuade you, which cannot be done in such a short letter. ${ }^{10}$

Two passages in the last few books of the De Trinitate push the terminal date even later than do the references in Augustine's correspondence. Book XIII.9.12 refers explicitly to the twelfth book of the De Civitate Dei. ${ }^{11}$ Since Orosius, in the prologue of his History, dated to 416 or $417,{ }^{12}$ says that Augustine was working on book XI of De Civitate Dei at the time, and since books XI-XIV of De Civitate Dei constitute a coherent group that is thought to have been written in a short space of time, this should provide a terminus post quem of 416/417 also for Book XII of De Civitate Dei, meaning that De Trinitate XIII cannot be earlier than that either. ${ }^{13}$ In Book XV.27.48 of De Trinitate, Augustine quotes extensively from his Tractatus on John 99 (sections 8-9), saying explicitly that he is quoting from a sermon later written down, so it is clear that Book XV was composed with Tractatus 99 already to hand. Haddan thought that this probably indicated a date of $c$. A.D. $417,{ }^{14}$ but La Bonnardière in fact argues that the Tractatus on John 99 cannot be earlier than 420, on the grounds that Tractatus 67 draws on Augustine's refutation of Vincent Victor in De natura et origine animae, which she dates to the winter of 419/420. ${ }^{15}$ This gives a terminus post quem for subsequent sections of the Tractatus on John, so Tractatus 99 cannot be before early 420, and De Trinitate XV must in turn be later than that.

A terminus ante quem for the publication of the De Trinitate is provided by Augustine's account of its unauthorised circulation, completion and publication in book II of the Retractationes. Augustine began the Retractationes probably in 427 and completed it a year or

\footnotetext{
${ }^{10}$ Trans. author. CSEL 44, p. 650: si parum hoc putatis, seruate uos ad legendos de trinitate libros, quos in nomine domini edere iamque dispono, ne forte illi persuadeant, quod tam in breuis epistula non potest.

${ }^{11}$ Hendrikx, 'Notes complémentaires', p. 559. De Trinitate XIII.9.12 (CCSL 50A, p. 398): on the question of whether souls return to the world in cycles of reincarnation: quod hic longum est demonstrare sed in libro duodecimo de Ciuitate Dei satis a nobis est quantum arbitror explicatum. '... a thing which here it is too long to demonstrate ; but it has been, as I think, sufficiently explained by us in the twelfth book of the City of God', trans. Arthur West Haddan, On the Trinity (The Works of Aurelius Augustine, Bishop of Hippo, 7; Edinburgh: T. \& T. Clark, 1873), p. 323, referring to De Civitate Dei XII.21.

12 Pedro Martínez Cavero, El pensamiento histórico y antropológico de Orosio (Antigüedad y Cristianismo: monografías históricas sobre la antigüedad tardía, 19: Universidad de Murcia, Servicio de Publicaciones, 2002), pp. 52-6.

13 Anne-Marie La Bonnardière, Recherches de chronologie augustinienne (Collection des études augustiniennes. Série Antiquité, 23; Paris: Études augustiniennes, 1965), p. 71.

${ }^{14}$ Haddan, On the Trinity, pp. v-vi; cf. Louis-Sébastien Le Nain de Tillemont, Mémoires pour servir à l'histoire ecclésiastique des six premiers siècles. Justifiez par les citations des Auteurs originaux: avec des notes pour éclaircir les difficultez des faits, \& de la chronologie, vol. 13, Seconde edition, revue \& corrigée ed. (Paris: Charles Robustel, 1710), p. 297.

${ }^{15}$ La Bonnardière, Recherches de chronologie augustinienne, pp. 65-9.
} 
so later, in $428 .{ }^{16}$ As the Retractationes are a retrospect of his published works, we can be certain that Augustine would not have begun them before he finished the De Trinitate, as the urgency of completing, at the request of bishop Aurelius and others, and correcting an unfinished version of the De Trinitate already in circulation, would surely have trumped work on the Retractationes. At the very latest, therefore, Augustine had published the De Trinitate by some time in 427 .

\section{Previous Scholarship on the composition and date of the Trinitate}

Within the constraints thus set — completion not before 420, not after 427—opinion has differed both on what Augustine might mean by saying that he started the work as a young man (iuvenis, which in colloquial usage simply seems to mean not quite middle-aged, and is used of men into their early or even middle fortie ${ }^{17}$ ), and on how soon after the latest terminus post quem offered by the evidence above the work was actually published. Already in the early eighteenth century Louis-Sébastien Le Nain de Tillemont had established that the letters and internal references indicated a terminus post quem of at least 416 and probably $417 .{ }^{18}$ The chronological framework was only slightly further fleshed out by Arthur West Haddan, who in his preface to the translation published in 1872 considered that Augustine must have started working on it in 400, when he was 46, and 'It was certainly still in hand in A.D. 416, inasmuch as in Book XIII. a quotation occurs from the 12th Book of the De Civitate Dei; and another quotation in Book XV., from the $90^{\text {th }}$ [sic: for 99th] lecture on St. John, indicates most probably a date of at least a year later, viz. A.D. 417. The Retractationes, which refer to it, are usually dated not later than A.D. 428'; but he considered that 'probably it was published ten or twelve years before this date', i.e. $416-418 .^{19}$

\footnotetext{
${ }^{16}$ Meredith F. Eller, 'The Retractationes of Saint Augustine', Church History 18 (3) (1949) pp. 172-83, at 172; Elizabeth Clark, 'On not retracting the unconfessed', in J. D. Caputo and M. J. Scanlon (eds), Augustine and Postmodernism: Confessions and Circumfession (Augustine and Postmodernism: Confessions and Circumfession: Indiana University Press, 2005), pp. 222-43, at 225. The terminus post quem is provided by the De Gratia et Libero Arbitrio and the De Correptione et Gratia, of late 426 or early 427 (Eller, 'The Retractationes of Saint Augustine', p. 172). Ep. 224 to Quodvultdeus tells us that Augustine had completed two books of the Retractationes dealing with 232 books of his previous works, but not yet the sermons or epistles, and that the work had to be put aside when Alypius of Thagaste sent him news of eight new books by Julian of Aeclanum, written in answer to Augustine, and sent him the first five of these, and he began working on responding to them (in addition to four that he had previously responded to).

${ }^{17}$ Cf. Livy 21.50, in which Hiero of Syracuse says that he had helped the Romans when he was a iuvenis, referring to events in $264 \mathrm{BC}$ when he was at least 41 .

${ }^{18}$ Le Nain de Tillemont, Mémoires pour servir à l'histoire ecclésiastique des six premiers siècles. Justifiez par les citations des Auteurs originaux: avec des notes pour éclaircir les difficultez des faits, \& de la chronologie, pp. 296-7.

${ }^{19}$ Haddan, On the Trinity, p. v.
} 
Until the 1950s there was no significant advance on Haddan's position: Seraphim Zarb proposed a broadly similar dating of $399-419 .{ }^{20}$ Other suggestions merely introduced confusion. Gustave Bardy thought the work was begun around 400, and finished some time between 412 and 416. ${ }^{21}$ François Glorie's view that the De Trinitate was completed in 412/413 has been rightly rejected: he misunderstood Augustine's statement in Retractationes II.15: Libros de Trinitate, quae Deus est, quindecim scripsi per aliquot annos ('I wrote the fifteen books on the Trinity, which is God, over a period of some years') to mean that he worked on the books for fifteen years, and having argued for a date of 397 for the beginning of the work, concluded that it was completed in 412/413. ${ }^{22}$ Peter Brown's biography of Augustine, published originally in 1967, accepts a date for composition between 399 and $419 .^{23}$

There are now two main schools of thought: one that argues for a first draft of most of the work completed relatively early, and then left unrevised for many years before eventual publication; and another that sees only a few books completed in the years immediately after 400 , and then the whole thing set aside for many years, with a further burst of work around 411-414, and then another delay before publication some time between 417 and 422 .

Ephraem Hendrikx was the proponent of the first of these alternatives; in the 1950s he argued that a first draft of all the books was completed probably between c. 399-405 (and certainly between 400 and 410), then put aside for a long time because Augustine was not satisfied with it but did not have the time sufficiently to revise it. The unauthorised circulation of the work (but only the first twelve books of a draft of fifteen that supposedly already existed) would have occurred, he thought, in 416, but without Augustine discovering this until 417 or later, and during Augustine's stay in Carthage in the summer of 418 it was the personal entreaties of the city's bishop, Aurelius, that prompted Augustine to revise it and publish it in mid 419. ${ }^{24}$ Much of Hendrikx's reasoning is pure speculation, based on an over-literal interpretation of the order in which works are discussed in the Retractationes, and assumptions

\footnotetext{
20 Seraphim F. Zarb, 'Chronologia operum S. Augustini. II. Augustini opera post ipsius episcopatum conscripta', Angelicum 10 (4) (1933) pp. 478-512, at 487-8.

${ }^{21}$ Gustave Bardy, Saint Augustin: l'homme et l'oeuvre, 6th ed. (Bibliothèque augustinienne; Paris: Desclée de Brouwer / Études augustiniennes, 1946), p. 363-5.

${ }^{22}$ François Glorie, 'Augustinus, De Trinitate. Fontes — Chronologia', Sacris Erudiri 16 (1965) pp. 203-55, esp. pp. 220-222. See Hombert 2000, pp. 52-3, n. 119.

${ }^{23}$ Peter Brown, Augustine of Hippo: A Biography (London: Faber \& Faber, 1967), p. 178, Chronological Table $\mathrm{C}=$ new ed., (London: Faber, 2000), p. 178.

${ }^{24}$ Ephraem Hendrikx, 'La date de composition du “De Trinitate” de saint Augustin', L'année théologique augustinienne 12 (4) (1952) pp. 305-16 = Hendrikx, 'Notes complémentaires', pp. 557-66; Alfred Schindler, Wort und Analogie in Augustins Trinitätslehre, vol. 4 (Mohr Siebrek Ek, 1965), p. 38.
} 
about Augustine's work rate. ${ }^{25}$ Hendrikx was followed, largely, by Edmund Hill, and his dating forms part of the basis for Hill's analysis of the doctrinal structure of the De Trinitate. $^{26}$

By contrast, Anne-Marie La Bonnardière, in a series of detailed studies of the chronology of Augustine's works, argued that only Book I is necessarily early (but revised and edited between 405 and 411, rather than 400); ${ }^{27}$ Books II-IV were written between 411 and $414,{ }^{28}$ as Book IV showed the influence of the anti-Pelagian controversy (and was thus later than 411, some of it probably later than 418, but the layers of revisions are difficult to disentangle); ${ }^{29}$ and books V-VII could not be pushed back before early $416 .{ }^{30}$ She considered that Books VIII-XII were composed in $417-418$, in parallel with Books XII-XIV of De Civitate Dei. Ep. 174 makes clear that the final stage, which occurred after parts of the work had been circulated by well-meaning friends of Augustine without his knowledge or permission, consisted of the prooemia to Books I, II, III, IV, V, the second part of Book XII, and Books XIII-XV. ${ }^{31}$ Book XIII must be later than 417 (because of its reference to Book XII of De Civitate Dei), and is probably later than 418, and Book XV of the De Trinitate which quotes the Tractatus on John 99 must date no earlier than 420. She thought the theft and unauthorised circulation of the work occurred in $418,{ }^{32}$ and placed the final stage of revision and publication in or after $420,{ }^{33}$ while conceding that it could stretch until 426: 'Disons donc que le livre XV a été rédigé entre 420 et 426 (il est alors recensé dans les Retractationes). ${ }^{34}$

${ }^{25} \mathrm{Cf}$. comments by Hombert, Nouvelles recherches de chronologie augustinienne, pp. 46-51.

${ }^{26}$ Edmund Hill, 'St Augustine's De Trinitate. The doctrinal significance of its structure', Revue d'Études Augustiniennes et Patristiques 19 (3-4) (1973) pp. 277-86, at 278 ('It seems he began it shortly after 400 AD, and only completed and published it some time after 420 AD.'); Edmund Hill, The Trinity (The Works of Saint Augustine: A Translation for the 21st Century, 1.5; Brooklyn, N.Y.: New City Press, 1991), p. 20 and n. 7.

${ }^{27}$ Anne-Marie La Bonnardière, 'Le De Trinitate de saint Augustin, confronté au livre XI de la Citè de Dieu', AEHE (Ve section) 85 (1976-77) pp. 343-6, at 346 (non vidi); quoted by Hombert, Nouvelles recherches de chronologie augustinienne, p. 52 n. 118.

${ }^{28}$ La Bonnardière, 'Le De Trinitate de saint Augustin, confronté au livre XI de la Citè de Dieu', p. 346 (non vidi), updating her earlier view that Book III had to be later than at least 409 or probably 411 (La Bonnardière, Recherches de chronologie augustinienne, p. 172).

${ }^{29}$ La Bonnardière, Recherches de chronologie augustinienne, p. 173, esp. nn. 2 and 3; Plagnieux, 'L'influence de la lutte antipélagienne sur le De Trinitate', pp. 817-26. La Bonnadière (p. 173 n. 2) hoped to treat the problem of the chronology of the early books of the De Trinitate in a future study, which never appeared.

${ }^{30}$ La Bonnardière, 'Le De Trinitate de saint Augustin, confronté au livre XI de la Citè de Dieu', p. 345-6 (non vidi); quoted by Hombert, Nouvelles recherches de chronologie augustinienne, p. 52 n. 118, and p. 77.

${ }^{31}$ La Bonnardière, Recherches de chronologie augustinienne, pp. 69-72, 167-9.

${ }^{32}$ La Bonnardière, 'Le De Trinitate de saint Augustin, confronté au livre XI de la Citè de Dieu', p. 346 (non vidi); quoted by Hombert, Nouvelles recherches de chronologie augustinienne, p. 52 n. 118.

${ }^{33}$ La Bonnardière, Recherches de chronologie augustinienne, pp. 69-72; 165-9; cf. La Bonnardière, 'Le De Trinitate de saint Augustin, confronté au livre XI de la Citè de Dieu', p. 346 (non vidi); quoted by Hombert, Nouvelles recherches de chronologie augustinienne, p. $52 \mathrm{n} .118$, where she thinks the final work of amending and editing could have occurred from 419 onwards.

${ }^{34}$ La Bonnardière, Recherches de chronologie augustinienne, p. 166. 
By 1990, however, she seems to have settled on the view that the whole work was complete by 421: 'C'est en 421 qu' Au[relius] reçoit le manuscrit définitif du trin. d'A., précédé de la lettre qui le dédie et qui raconte les vicissitudes de sa rédaction (ep. 174; retr. 2,15)' ${ }^{35}$

Othmar Perler and Jean-Louis Maier, in their study of Les voyages de St Augustin, cautiously considered that the De Trinitate was finished between 422 and 427, relying on La Bonnadière, with the additional suggestion that since Augustine was occupied with the Pelagian controversy in 420 and 421, the De Trinitate was probably finished in 422 or later. ${ }^{36}$

Pierre-Marie Hombert essentially follows La Bonnardière in distinguishing perhaps three major phases of work: Book I between 400 and 403; books II-IV between 411/12 and 414; and the remainder sometime up till 422 (for the latter proposition he gives no argument, and seems simply to be following La Bonnardière's later limit, or Perler and Maier), but without pushing the date towards the later end of the possible bracket). ${ }^{37}$

Others have not engaged in detail with these two contrasting positions (Hendrikx/Hill vs. La Bonnadière/Hombert), contenting themselves with the broad chronological limits. Michel Barnes in 1999 thought that virtually all of the de Trinitate had been written by AD 419, when Augustine received the Arian Sermon, while Mary Clark in 2001 asserted that it was begun in 399 and finished 'possibly before 421'.38 Other than Perler and Maier, whose judiciously broad dating has been largely ignored, nobody seems to have had much appetite for pushing the completion of the work very far beyond 421 or 422 ; i.e. close to the latest terminus post quem established by the chronological cross-referencing of Augustine's other works.

\section{The Walls of Carthage}

In all of these debates, a crucial piece of evidence for dating the completed work has been overlooked. In Book IX.6.10 Augustine discusses how we imagine things we have not seen on the basis of comparable things that we have seen, using the example of how the fact that he has

35 Anne-Marie La Bonnardière, 'Aurelius episcopus', in Cornelius Mayer (ed.), Augustinus-Lexikon (Augustinus-Lexikon Schwabe \& Co. AG: Basel, 1990), pp. 550-66, at 565.

${ }^{36}$ Othmar Perler and Jean Louis Maier, Les Voyages de saint Augustin (Paris: Etudes augustiniennes, 1969), p. 376, and n. 2; following La Bonnardière, Recherches de chronologie augustinienne, p. 166.

${ }^{37}$ Hombert 2000, pp. 45-80; see esp. table on p. 8, and p. 53: 'Augustin a commencé l'ouvrage vers 400-403, écrivant alors le livre I (sauf le Prooemium, bien entendu). Il a ensuite interrompu la rédaction de l'oeuvre pendant de longues années, pour ne reprendre celle-ci qu'à la fin de 411 ou au début de 412. De sorte que les livres II-IIIIV sont de 411/412 - 414.'

${ }^{38}$ Michel René Barnes, 'Exegesis and Polemic in Augustine's De Trinitate I', Augustinian Studies 30 (1) (1999) pp. 43-59; Mary T. Clark, 'De Trinitate', in Eleonore Stump and Norman Kretzmann (eds), The Cambridge Companion to Augustine (The Cambridge Companion to Augustine; Cambridge: Cambridge University Press, 2001), pp. 91-102, at 91. 
seen the defensive walls (moenia) ${ }^{39}$ of Carthage enables him to envisage the city walls of Alexandria, which he has never seen:

unde etiam phantasias rerum corporalium per corporis sensum haustas et quodam modo infuses memoriae, ex quibus etiam ea quae non uisa sunt ficto phantasmate cogitantur siue aliter quam sunt siue fortuito sicuti sunt, aliis omnino regulis supra mentem nostram incommutabiliter manentibus uel approbare apud nosmetipsos uel improbare conuincimur cum recte aliquid approbamus aut improbamus. nam et cum recolo Carthaginis moenia quae uidi et cum fingo Alexandriae quae non uidi easdemque imaginarias formas quasdam quibusdam praeferens, rationabiliter praefero. uiget et claret desuper iudicium ueritatis ac sui iuris incorruptissimis regulis firmum est, et si corporalium imaginum quasi quodam nubilo subtexitur, non tamen inuoluitur atque confunditur.

Whence also, even in the case of the images of things corporeal which are drawn in through the bodily sense, and in some way infused into the memory, from which also those things which have not been seen are thought under a fancied image, whether otherwise than they really are, or even perchance as they are ;- even here too, we are proved either to accept or reject, within ourselves, by other rules which remain altogether unchangeable above our mind, when we approve or reject anything rightly. For both when I recall the walls of Carthage which I have seen, and imagine to myself the walls of Alexandria which I have not seen, and, in preferring this to that among forms which in both cases are imaginary, make that preference upon grounds of reason;

\footnotetext{
${ }^{39}$ The normal meaning of moenia in Classical Latin is 'city walls' or 'defences'. In late antiquity it sometimes also came to mean 'public buildings', as Bryan Ward-Perkins, From classical antiquity to the Middle Ages. Urban public building in northern and central Italy, AD 300-850 (Oxford: Oxford University Press, 1984), p. 46 n. 39 , observes (though to say that the word became 'normally used' in this way appears to me an exaggeration, at least as far as the early fifth century is concerned). Ward-Perkins notes that the Theodosian Code and Cassiodorus use moenia in the sense of public buildings, but also that Claudian (De VI consulatu Honorii, line 203; AD 404) and Maximus of Turin (Sermo 85.2; early fifth-century) continue to use the word in its traditional sense of defences. In fact, while Cassiodorus does sometimes use moenia to mean public buildings (e.g. Variae III.29, VII.6, VII.17), in other places he also uses it to mean city walls (Variae III.44, and III.49)—see Giuseppina Della Valle, 'Moenia', Rendiconti della Accademia di archeologia, lettere, e belle arti 33 (1958) pp. 167-76, at 175. Likewise, while sections 4.13.5 and 15.1.32, 33 and 39 of the Theodosian Code do use moenia publica to refer to public buildings; other sections of the Code (9.40.20 and 16.5.6) use moenia to mean the city walls as city limits. Indeed, in legislation, where moenia is used to mean 'public buildings' it is usually qualified by the adjective publica (e.g. Codex Iustinianus 11.32.3; 11.70.3; cf. also CIL IX.2337, 2449 and 2639, cited by Ward-Perkins p. 231). It is clear however that Augustine uses moenia without further qualification in the sense of 'city walls' (Confessiones VIII.6; XIII.30; De Civitate Dei I.33; II.27; III.2; III.13; III.15; III.18; III.20), and that when he wants to include buildings as well as city walls he uses a phrase like moenia et tecta, moenia parietesque, or moenibus atque domibus (De Urbis Excidio ch. 6 lines 233, 267, 273; De Civitate Dei II.22; XXI.24). There can thus be no doubt that when Augustine uses moenia in De Trinitate IX.6.10 he means the city walls of Carthage and Alexandria, and he is thinking of the shape (forma) or silhouette that the city presents to a traveller approaching it.
} 
the judgment of truth from above is still strong and clear, and rests firmly upon the utterly indestructible rules of its own right; and if it is covered as it were by cloudiness of corporeal images, yet is not wrapt up and confounded in them. ${ }^{40}$

Although Punic Carthage had had a defensive wall circuit, it was destroyed along with the rest of the Punic city in 146 BC, and the Roman colony founded some 100 years later was an open city, entirely unwalled; it remained undefended until the reign of Theodosius II. The Chronica Gallica de 452 records the construction of a wall circuit at Carthage under the second year of Theodosius' reign, $\mathrm{AD} 425$ :

muro Cartago circumdata, quae ex tempore, quo uetus illa destructa est, sanctione Romanorum, ne rebellioni esset munimentum, muris non est permissa uallari.

Carthage was enclosed by a wall; from that time that the old city had been destroyed, by command of the Romans it had not been permitted to defend it with walls, lest it be a stronghold of rebellion. ${ }^{41}$

We shall return in a moment to the question of the chronological accuracy of the Chronica and the date of the walls.

The archaeological evidence confirms that the surviving remnants of its late antique defensive circuit do indeed belong to the early fifth century. ${ }^{42}$ Almost nothing of the original

${ }^{40}$ De Trinitate IX.6.10, CCSL 50 pp. 302-3; trans. Haddan, On the Trinity, p. 231.

${ }^{41}$ Chronica Gallica de 452, edited Richard Burgess, 'The Gallic Chronicle of 452: A new critical edition with a brief introduction', in R. W. Mathisen and Danuta Shanzer (eds), Society and Culture in Late Antique Gaul. Revisiting the Sources (Society and Culture in Late Antique Gaul. Revisiting the Sources; Aldershot: Ashgate, 2001), pp. 66-84.

${ }^{42}$ For archaeological reports on the Theodosian wall of Carthage, see: Henry R. Hurst, 'Excavations at Carthage 1974. First Interim Report', The Antiquaries Journal. The Journal of the Society of Antiquaries of London 55 (1) (1975) pp. 11-40, Henry R. Hurst, 'Excavations at Carthage, 1975. Second interim report', The Antiquaries Journal. The Journal of the Society of Antiquaries of London 56 (2) (1976) pp. 177-97, Henry R. Hurst, 'Excavations at Carthage 1976. Third interim report', The Antiquaries Journal. The Journal of the Society of Antiquaries of London 57 (2) (1977) pp. 232-61, Henry R. Hurst, 'Excavations at Carthage, 1977-8: fourth interim report', The Antiquaries Journal. The Journal of the Society of Antiquaries of London 59 (1) (1979) pp. 19-49, Henry R. Hurst and Stephen P. Roskams, Excavations at Carthage: The British Mission, vol. I.1 (Sheffield: The Department of Prehistory and Archaeology (Publications), University of Sheffield, 1984), D. F. Williams, 'Note on charcoal content in city-wall mortar', in Henry R. Hurst and Stephen P. Roskams (eds), Excavations at Carthage: the British mission (Excavations at Carthage: the British mission; Sheffield: University of Sheffield, Department of Prehistory and Archaeology, 1984), pp. 81; Colin M. Wells and Edith Mary Wightman, 'Canadian excavations at Carthage, 1976 and 1978: the Theodosian Wall, Northern Sector', Journal of Field Archaeology 7 (1) (1980) pp. 43-63, Colin M. Wells, 'Carthage. The Late Roman Defences', in, Roman frontier studies 1979 (Roman frontier studies 1979; Oxford, 1980), pp. 999-1004, Colin M. Wells, 'The Defense of Carthage', in John Griffiths Pedley (ed.), New light on ancient Carthage (New light on ancient Carthage; Ann Arbor: The University of Michigan Press, 1980), pp. 47-65, Colin M. Wells, J. Gallagher, and M. Goodfellow, 'Further Light on the Late Defences at Carthage', in C. Unz (ed.), Studien zu den Militärgrenzen Roms III: Akten des 13. Internationalen Limeskongress, Aalen, 1983 (Studien zu den Militärgrenzen Roms III: Akten des 13. Internationalen Limeskongress, Aalen, 1983; Stuttgart: Böhlau Verlag, 1986), pp. 673-9. 
c. $9.5 \mathrm{~km}$ circuit, with projecting towers and perhaps nine gateways, ${ }^{43}$ survives above ground, but the course of the wall has been traced from aerial photography, topographical indications, geophysical survey, and excavations across its line. The British excavations on the Salammbo site (Avenue Bourgiba) showed that the wall was cut into soil containing late fourth-century coins and pottery; within the matrix of the wall were found a late fourth-/early fifth-century marble head and three coins, of which the latest, of Honorius, gives a terminus post quem of 402/423. ${ }^{44}$ Here the wall was $3.5 \mathrm{~m}$ wide with 'a core of grey charcoal-flecked rubble'; it had originally been faced with squared ashlar blocks, although the facing had been much robbed. ${ }^{45}$ The wall and its core had been more extensively robbed in the Canadian excavations in the north-west part of the site, known by the modern Arabic name as the Teurf es-Sour, the 'bank of the wall', but here too enough survived to show that it had been constructed with the same charcoal-flecked mortar, and the remains of the core and the width of the robber trench suggested similar dimensions as on the Salammbo site. ${ }^{46}$

The statement about the wall of Carthage in the Chronica Gallica de 452 is embedded in a sequence of events following the death of Honorius in 423: the usurpation of John, the expedition of Sigisvult to Africa against Boniface, the murder of the prefect Exuperantius in Gaul by the army, the construction of the walls of Carthage, and then the defeat and capture of John by an eastern Roman army at Ravenna in 425. Frank Clover, working from Mommsen's edition of the Chronica Gallica de 452, considered that 'The exact date is a matter for conjecture: the margin of chronological error in this work varies from two to five years. The wall might therefore have been built at any time between about 420 and 430'; but that 'It is a reasonable guess that [Boniface] ordered the construction of the wall between 423 and $425^{\prime}$, in the face of the usurpation of John. ${ }^{47}$ The most recent edition (2001) of the Chronica de 452 corrects chronological errors in Mommsen's edition of 1894, and establishes that its chronology is reasonably accurate, more so than used to be thought on the basis of Mommsen's edition. $^{48}$

\footnotetext{
${ }^{43}$ Hurst and Roskams, Excavations at Carthage: The British Mission, pp. 36-7, 41.

${ }^{44}$ Hurst, 'Excavations at Carthage 1976. Third interim report', p. 255; Hurst and Roskams, Excavations at Carthage: The British Mission, p. 16.

${ }^{45}$ Hurst, 'Excavations at Carthage 1974. First Interim Report', pp. 35-38, (quote from p. 36); Hurst and Roskams, Excavations at Carthage: The British Mission.

${ }^{46}$ Wells and Wightman, 'Canadian excavations at Carthage, 1976 and 1978: the Theodosian Wall, Northern Sector', pp. 49-52, 59-63.

${ }^{47}$ Frank M. Clover, 'Carthage in the age of Augustine', in John H. Humphrey (ed.), Excavations at Carthage 1976 conducted by the University of Michigan (Excavations at Carthage 1976 conducted by the University of Michigan; Ann Arbor: The University of Michigan Press, 1978), pp. 1-14, at 9.

${ }^{48}$ Burgess, 'The Gallic Chronicle of 452: A new critical edition with a brief introduction', p. 57-9; cf. Theodor Mommsen, Chronica Minora, saec. IV. V. VI. VII, vol. 2 (Monumenta Germaniae historica inde ab anno Christi
} 
The Chronica correctly puts the death of Honorius and the usurpation of John in 423, but the expedition of Sigisvult, which it places in 424, did not in fact happen until 427 or 428 ; the author of the Chronica seems to have confused Sigisvult's expedition in the late 420 s with the expedition of John's forces against Boniface in 424, which Prosper's Epitoma Chronicon says weakened John's position in Italy since part of his army was fighting Boniface in Africa. ${ }^{49}$ The prefect Exuperantius was killed in a mutiny in 424, according to Prosper, rather than 425 as the Chronica says; but the defeat of John by the Eastern army did indeed happen in 425, the year in which the Chronica places it. On the evidence of the Chronica, the date of the construction of the walls of Carthage, sandwiched between the death of Exuperantius and the defeat of John, could be either 424 or 425.

Moreover, we can restrict the possible date range for the construction of the wall to before 427, since the mention of it in the De Trinitate guarantees its existence before 427 at the latest. ${ }^{50}$ And since it is unlikely that Augustine visited Carthage after 425 (see further below), we can concur with Clover's suggestion that the decision to construct the wall was made on Boniface's orders, between 423 and 425, after the usurpation of John in 423; but since the wall can hardly have been finished in 423, even if Boniface started constructing it soon after the death of Honorius in August, or more likely the usurpation of John in November 423, we are left with a choice of either 424 or 425 for the completion of the wall circuit. All of this is consistent with the archaeological terminus post quem. Augustine therefore could not have seen the walls of Carthage before AD 424 or 425, for the simple reason that they did not yet exist.

Indeed, Augustine's example about 'preferring this to that among forms which in both cases are imaginary, make that preference upon grounds of reason' gains added point from the fact that when he wrote the walls of Carthage to which he refers had just recently been built, whereas the walls of Alexandria were $c .750$ years old; he is imagining a very old structure on the basis of his familiarity with a modern one, and he knows that there is a dissonance here.

\section{The date of the De Octo Dulcitii Quaestionibus and Augustine's visit to Carthage}

Can we narrow down further the date (between 424 and 427, when the De Trinitate was complete) when Augustine saw the walls of Carthage? His stay in Carthage for the Council of $418 / 419$ is clearly much too early; the walls had not yet been built. Perler and Maier, in their

\footnotetext{
quingentesimo usque ad annum millesimum et quingentesimum. Auctores antiquissimi, 11; Berolini: apvd Weidmannos, 1894).

${ }^{49}$ Prosper, Epitoma Chronicon, Year CCCXCVII (= AD 424).

${ }^{50} \mathrm{We}$ can thus reject Colin Wells' very tentative suggestion that the wall may have been unfinished in 428 : Wells, 'The Defense of Carthage', p. 52.
} 
study of Augustine's travels, adduce three pieces of evidence that show that Augustine visited Carthage at some point in the mid 420s: ${ }^{51}$

1) Sermo 114 is entitled Sermo habitus ad mensam sancti Cypriani de die dominica praesente comite Bonifatio de remittendum fratribus ('Sermon preached at the shrine of St Cyprian on Sunday, in the presence of Count Boniface, on forgiving one's brothers'). The sermon was therefore preached at the site of Cyprian's martyrdom on the outskirts of Carthage, but evidently not before the last quarter of 423 , as Boniface was made comes Africae after the death of Honorius on 15 August 423, and comes domesticus in $425 .^{52}$

2) A passage in the final book of De Civitate Dei, completed in 426, mentions, in the context of miracles performed by the intercession of St Stephen, at Uzalis and elsewhere, that Augustine had recently (nuper) been at Uzalis. ${ }^{53}$ Uzalis lies north-west of Utica, just off the route to Hippo Diarrhytus, and therefore close to the coastal route between Hippo Regius and Carthage. Augustine would presumably have stopped here on the way to or from Carthage, to visit his old friend Evodius who was bishop of Uzalis. One cannot perhaps push the definition of nuper too far, since Augustine occasionally uses it of events some ten years before, but given that Sermo 114 already puts Augustine in Carthage in or after 423, the stop at Uzalis was presumably made on the way there or the way back on the same trip. ${ }^{54}$

3) The third piece of evidence concerns a visit to Carthage that Augustine says that he made just after Easter in one of these years. At the start of the De Octo Dulcitii Quaestionibus, written in answer to eight theological questions sent to him by Dulcitius, Augustine apologises for the delay in responding to Dulcitius' questions. He explains that he received Dulcitius' letter during the Easter festivities and immediately after the Easter celebrations he left for Carthage, and was away for three months. ${ }^{55}$ This journey must have happened sometime in 421-426, after Augustine wrote the Enchiridion (chapters XVIII and XIX of which are quoted in the De Octo Dulcitii Quaestionibus), and before the Retractationes, begun in 427, which mention the De Octo Dulcitii Quaestionibus. ${ }^{56}$ Since Enchiridion XXIII mentions St Jerome, who died on 30 September 420, as already dead, the earliest year that the visit to Carthage referred to in the De Octo Dulcitii Quaestionibus could have occurred would be 421.

${ }^{51}$ Perler and Maier, Les Voyages de saint Augustin, pp. 373-80.

52 Ibid., pp. 379-80. For Boniface's career, see PLRE 3, pp. 239-240 s.v. Bonifatius 3.

${ }^{53}$ De Civitate Dei XXII.8 (CCSL 48, p. 824).

${ }^{54}$ Perler and Maier, Les Voyages de saint Augustin, p. 380. De Octo Dulcitii Quaestionibus I, 11. $263-349$ reproduces Enchiridion XV3III.67-69 and II. 11. 57-86 reproduce Enchiridion XXIX.109-110 (see CCSL 44A p. cviii); and Retractationes II.65 mentions the De Octo Dulcitii Quaestionibus.

${ }^{55}$ De Octo Dulcitii Quaestionibus, Praefatio; CCSL 44A, p. 253.

${ }^{56}$ Perler and Maier, Les Voyages de saint Augustin, pp. 373-4. 
Within this time bracket the date of the work has been much discussed in the belief that the text specified the date of Easter, which should then allow calculation of the year-except that the date given in the manuscripts (a.d. III Kal. Aprilis, or $30^{\text {th }}$ March) did not match the date of Easter for any year in Augustine's lifetime except 419 and 430, both of which are already ruled out as they lie outside the possible chronological limits for the composition of the work. Considerable ingenuity was therefore exercised in debating which of the possible textual emendations to the date is most plausible, or alternatively trying to argue that the African church might have celebrated Easter on a different date in one of these years. ${ }^{57}$ All these arguments were rendered redundant when in 1970 A. Mutzenbecher showed that the original manuscript reading related not to the date of Easter at all, but to the date during the Easter period - either Holy Week or Easter Week — when Augustine received Dulcitius' letter (which, after all, was the point: he was excusing his delay in replying). ${ }^{58}$ The superior reading, preserved in a thirteenth-century manuscript, gave the text:

per pascha quippe hoc anno, quo domi cum meis fui, tertio calendis aprilis a Carthagine mihi missa litteras tuae dilectionis accepi. post eos autem dies sanctos confestim Carthaginem sum profectus ...

Since in the Easter period in this year, in which I was at home with my people, on the $30^{\text {th }}$ March I received the letters sent to me from Carthage of your affection. After those holy days I set out immediately for Carthage ... 59

As Augustine set out just after the Easter period, the year must be one in which $30^{\text {th }}$ March fell in the week before Easter or the week after Easter. This gives three possibilities within the range AD 421-426 (Table 1): 421, when 30 ${ }^{\text {th }}$ March was on Wednesday of Holy Week and Easter fell on April $3^{\text {rd }} ; 422$, when $30^{\text {th }}$ March fell after Easter, on Thursday of Easter Week; and 424, when $30^{\text {th }}$ March was Palm Sunday, and Easter fell on $6^{\text {th }}$ April. ${ }^{60}$ But 422 is excluded on other grounds, since between April and July of that year Augustine was at Hippo and Fussala, dealing with the problems caused by Antoninus, bishop of Fussala; he could not have

\footnotetext{
${ }^{57}$ See for discussion of the problem, Le Nain de Tillemont, Mémoires pour servir à l'histoire ecclésiastique des six premiers siècles. Justifiez par les citations des Auteurs originaux: avec des notes pour éclaircir les difficultez des faits, \& de la chronologie, pp. 843, 1027-8; Seraphim F. Zarb, 'Chronologia operum S. Augustini', Angelicum 10 (3) (1933) pp. 359-96, pp. 375-6 (= Seraphim F. Zarb, Chronologia operum S. Augustini secundum ordinem Retractationum digesta (Romae: Pont. Inst. Angelicum, 1934), p. 18); Perler and Maier, Les Voyages de saint Augustin pp. 373-80.

${ }^{58}$ A. Mutzenbecher, 'Zur Datierung von Augustinus De octo Dulcitii quaestionibus', Sacris Erudiri 19 (19691970) pp. 365-79, esp. pp. 373-9.

59 and not per pascha quippe hoc anno, quo dominicum eius fuit tertio calendis aprilis a Carthagine mihi missa litteras ..., 'Since in the Easter period in this year, in which Easter Sunday was on $30^{\text {th }}$ March, I received the letters ...'. Ibid.

${ }^{60}$ Mutzenbecher, 'Zur Datierung von Augustinus De octo Dulcitii quaestionibus', p. 377.
} 
gone to Carthage at this period. ${ }^{61}$ Mutzenbecher points out that the chronological presentation of Augustine's writings in the Retractationes also excludes 421 as a possibility: the De Octo Dulcitii Quaestionibus is the $91^{\text {st }}$ of the 93 works mentioned (Retractationes II.65), and the latest work before it that can be securely dated is the $77^{\text {th }}$ work, Gesta cum Emerito Donatista (Retractationes II.51), dated to $20^{\text {th }}$ September 418. It does not seem plausible to try to cram the intervening thirteen works into the period between September 418 and Easter 421, and then date only the final two works to the period 421-427; by contrast, dating these thirteen works between 418 and 424 gives a much more reasonable distribution of composition. ${ }^{62}$ Augustine's three-month visit to Carthage just after Easter must therefore have been made in 424 .

Table 1: The dates of Easter in the Julian calendar between AD 419 and 430, calculated on the Roman Supputatio (based on Mosshammer 2008, Table 8).

\section{Year Date}

419 March $30^{\text {th }}$

420 April $18^{\text {th }}$

421 April $3^{\text {rd }}$

422 March $26^{\text {th }}$

423 April 15th

424 April 6th

425 March $22^{\text {nd }}$

426 April 11th

427 April 3rd

428 April 15th

429 April 7th

430 March $30^{\text {th }}$

\section{Roman calendrical notation}

a.d. III Kal. Aprilis

a.d. XIV Kal. Iuni

a.d. III Non. Aprilis

a.d. VII Kal. Aprilis

a.d. XVII Kal. Maias

a.d. VIII Id. Aprilis

a.d. XI Kal. Aprilis

(April $19^{\text {th }}$ a.d. XIV Kal. Maias)

a.d. III Id. Aprilis

a.d. III Non. Aprilis

a.d. XVII Kal. Maias

(April 22nd a.d. X Kal. Aprilis)

a.d. III Kal. Aprilis

${ }^{61}$ Perler and Maier, Les Voyages de saint Augustin pp. 372-3, 376; Ep. 29*.

${ }^{62}$ Mutzenbecher, 'Zur Datierung von Augustinus De octo Dulcitii quaestionibus', p. 378. 


\section{Church Councils in 424 and 425}

Augustine's visit to Carthage in 424 may well have been motivated, indeed required, by a church council at Carthage, although that cannot have occupied all his time there for three months; and moreover, if he did go for a council in 424, he may also have gone for another one in 425 . We know of a church council that was held at Carthage in a year that has variously been thought to be 424,425 , or $426 .{ }^{63}$ The council is mentioned in a record of the Council of Carthage in 525, which cites one of the canons of the $20^{\text {th }}$ Council of Carthage, held under bishop Aurelius, Ut nullus ad romanam ecclesiam audeat appellare, 'That no one dare appeal to the Roman church'. This evidently relates to the affair of Apiarius about which the African bishops wrote to Pope Celestinus (423-432), in the letter entitled Optaremus. ${ }^{64}$ Apiarius, a priest in the diocese of Sicca Veneria in Africa, had been excommunicated for various kinds of misconduct, had appealed directly to Pope Zosimus, resulting in his trial at the Council of Carthage in 419, and the lifting of his excommunication. Subsequently he had become a presbyter at Thabraca (Tabarka), but was again accused of misdemeanours, this time certainly sexual, whereupon he again appealed over the head of bishop Aurelius of Carthage directly to the new pope, Celestinus. ${ }^{65}$ This resulted in a trial at another Council of Carthage, the $20^{\text {th }}$, to which Celestinus sent his legate Faustinus, who had already annoyed the African bishops in 419 by defending Apiarius. It was in the wake of this second trial, at which Apiarius eventually confessed his crimes, that the African bishops wrote the Optaremus to Pope Celestinus objecting strongly to Roman interference in affairs of the African church. There is no evidence that Augustine was present, and his name does not appear among the signatories to the letter, but that may simply be because the signatories are all bishops of Africa, the province in which

${ }^{63}$ Charles Munier, Concilia Africae, a. 345 - a. 525 (Corpus Christianorum, series Latina, 149; Turnhout: Brepols, 1974), pp. 166-72; see p. xxxv for the date. Tillemont 1710, p. 860, puts it 'apparement en 426', but without justification. It is presumably Tillemont's assertion that lies behind Maassen's dating to either 425 or 426 : Friedrich Maassen, Geschichte der Quellen und der Literatur des canonischen Rechts im Abendlande bis zum Ausgange des Mittelalters, vol. 1 (Graz: Verlag von Leuschner \& Lubensky, 1870), p. 183. As Mutzenbecher, 'Zur Datierung von Augustinus De octo Dulcitii quaestionibus', p. 378 n. 53, observes, others put the council in 424 without giving any reason: Karl Joseph von Hefele, A History of the Councils of the Church: From the Original Documents, vol. 2 (Edinburgh: T. \& T. Clark, 1876), p. 480; Karl Joseph von Hefele, Histoire des conciles : d'après les documents originaux, vol. 2 (Paris: Letouzey et Ané, 1908), p. 214; Frank Leslie Cross, 'History and fiction in the African Canons', The Journal of Theological Studies 12 (2) (1961) pp. 227-47, p. 243; Charles Munier 'Un canon inédit du XX' concile de Carthage: «Ut nullus ad Romanam ecclesiam audeat appellare »', Revue des Sciences Religieuses 40 (2) (1966) pp. 113-26, p. 118, n. 16, p. 124.

${ }^{64}$ Munier 'Un canon inédit du XX ${ }^{\mathrm{e}}$ concile de Carthage', p. 114.

${ }^{65}$ On the Apiarius affair, see Jane E. Merdinger, Rome and the African church in the time of Augustine (New Haven and London: Yale University Press, 1997), pp. 183-99; Brent D. Shaw, Sacred Violence: African Christians and Sectarian Hatred in the Age of Augustine (Cambridge: Cambridge University Press, 2011), pp. 404-7. 
Apiarius was priest, whereas Augustine's see was in Numidia. We should certainly expect Augustine to have attended an African synod.

The date of this council is broadly suggested by the prologue to a council that followed it, held at Hippo on 24 September 427, which implies that a council of the African church had not been held for some two years - and that this was unusual. Bishop Aurelius of Carthage opened the council of 427 by saying Sanctitas uestra melius recolit qua necessitate factum est ut instituta concilii solemnitas per biennium cessaret. nunc quia adiuuante Deo certa prouintia factum ...,'Your holinesses will well remember by what necessity it was done that the solemn institution of a council should cease for a biennium. Now that with the help of God the province has been made secure ...' ${ }^{66}$ Unfortunately, we, posterity, are not told precisely what that necessity was, but the timing, the reference to the re-establishment of security in the province, and Aurelius' studied avoidance of specifically mentioning the cause, suggests that the war in North Africa against Boniface in 426/427 was the reason. ${ }^{67}$ One can see why it would be not merely tactful, but politically important for Aurelius, in a minuted meeting, to avoid explicit reference to the conflict between Boniface, currently wielding military command in Africa, and the imperial throne to which he was at the time opposed.

Munier took Aurelius' words to mean that the previous council might have been held in either 424 or $425,{ }^{68}$ as did Merdinger, ${ }^{69}$ but surely 425 is to be preferred; it is difficult to see how, from the perspective of a council held in late 427 , a council in 424 could be considered as being within a biennium rather than a triennium. La Bonnardière also dated this council to 425 rather than $424 .{ }^{70}$ The fact that the two-year gap before the council of 427 was considered exceptional should imply that there had been councils in both 424 and 425; and Augustine may very well therefore have travelled to Carthage in 425 as well as in 424 . Indeed, it is possible

${ }^{66}$ Munier, Concilia Africae, p. 250 (Concilium Hipponense).

${ }^{67}$ certa prouintia is the original manuscript reading, emended unnecessarily by the Ballerini brothers to certa prouidentia (Johannes Lambertus Maria de Lepper, De rebus gestis Bonifatii comitis Africae et magistri militum (Tilburg: W. Bergmans, 1941), p. 58). Prosper's Epitoma Chronicon puts the expedition against Boniface under Mavortius, Gallio, and Sanoeces in 427, but it also puts both Sigisvult's follow-up expedition following its defeat, and the Vandal crossing to Africa (which in fact was in May 429) in the same year. Clearly Prosper has recorded the events of more than one year under the entry for 427, and it seems to me possible that Mavortius, Gallio, and Sanoeces may have invaded Africa in 426, even if their defeat, and the expedition of Sigisvult in its wake, did not occur until 427. The Chronica Gallica de 452 puts Sigisvult's expedition in 424-too early, and apparently a confusion with the expedition of 424/425 of John's forces against Boniface. De Lepper, De rebus gestis Bonifatii, pp. 57-63 also argues persuasively for 426 as the date of the expedition of Mavortius, Gallio, and Sanoeces, on the grounds that it prevented the holding of a pan-African synod in 426 and the early part of 427.

${ }^{68}$ Munier, Concilia Africae.

${ }^{69}$ Merdinger, Rome and the African church in the time of Augustine, pp. 184-5.

${ }^{70}$ La Bonnardière, 'Aurelius episcopus', p. 565. 
that 425 rather than 424 may have been the occasion for either or both of sermon 114 at the mensa of St Cyprian, and the visit to Uzalis on the way to or from Carthage.

It has generally been assumed that the $20^{\text {th }}$ Council of Carthage, dealing with the second instance of the Apiarius affair, must have been the one immediately preceding the Council of Hippo in 427 . This is certainly possible, but it is by no means a necessary conclusion. It cannot have happened before the accession of Pope Celestinus in 423, but we have just seen that Bishop Aurelius' introduction to the Council of Hippo seems to imply that there were councils in both 424 and 425 , and the $20^{\text {th }}$ Council might have been either one of these.

The evidence of the De Octo Dulcitii Quaestionibus thus indicates that Augustine visited Carthage for an extended period in 424, while such evidence as can be deduced from the dates of the councils of Carthage suggests that he may also have made another trip in 425 for a council then, although this is less certain. While we cannot therefore use the chronology of his visits to establish a terminus ante quem that would allow us to decide between 424 or 425 as a date for the completion of the walls, we can propose that he saw either the partially built or even completed walls in 424 , or the completed walls in 425 , or both.

\section{Completion and Publication of the De Trinitate}

We therefore have an internally consistent sequence in which Augustine went to Carthage for a synod in either 424 or 425 , or both, saw the new city walls there, preached a sermon at the mensa of Cyprian in the presence of the comes Boniface, and was persuaded by Aurelius and others to complete the De Trinitate. At the time that he wrote Book IX of the De Trinitate Augustine was assuredly back in Hippo- he recalls the walls of Carthage, which he has seen, but he seems no longer to be there.

The completion and publication of the work thus happened between his return from Carthage in either 424 or 425, and the commencement of work on the Retractationes in 427. But we can go further: the terminus post quem thus established applies in particular to Book IX, which mentions the walls, and it follows from this that the whole episode of the theft and unauthorised circulation of an incomplete manuscript of the De Trinitate must also be after 424/425, since Augustine's account of it says that (1) he composed the work sequentially (he dictated it, and the argument proceeded in steps with later books building on the earlier ones), and (2) he was part-way through Book XII when the work was leaked. Indeed, in the letter to Aurelius which he asked to be prefaced to copies of the work, he says that the final version was 'corrected (not as I wished, but as I could, lest the Books should differ very widely from those which had surreptitiously got into people's hands)', and he took care to specify how the final 
work differed from the unauthorised version already in circulation: 'There are some persons, however, who have the first four, or rather five, Books without the prefaces, and the twelfth with no small part of its later chapters omitted. But these, if they please and can, will amend the whole, if they become acquainted with the present edition.' It seems that he added the later books, and prefaces to the first five books, but did not substantially revise what he had already written. Book IX is not mentioned as one of the incomplete or altered books, and it does not therefore appear that Augustine added the example about the walls of Carthage to Book IX after the unauthorised circulation had happened.

This means that the whole of the following sequence has to be fitted into the period 424/425-427: the writing of Book IX (and perhaps Book VIII as well), Books X, XI and the first half of XII; the unauthorised circulation of the incomplete work; Augustine's discovery of the fact; his initial reaction to abandon the project; his persuasion by Aurelius and others to continue; the completion of Books XII-XV; the letter to Aurelius, and the eventual publication. If the otherwise undated Ep. 173A, in which Augustine says that he is now minded to publish his books on the Trinity (de trinitate libros, quos in nomine domini edere iamque dispono) refers to Augustine's change of mind after the initial shock of the discovery that an incomplete version of the De Trinitate was in circulation, then this letter should now also be dated to 424/425-427. Even if it was on his three-month visit to Carthage in April-July 424 that he saw the walls of Carthage (and not on a visit in 425), he cannot have returned from that visit before mid July 424, and it is therefore difficult to see publication of the whole work before 425 at the earliest.

The position of Hendrikx and Hill, that a first draft of the entire De Trinitate was completed early on and then put aside until well-meaning colleagues circulated the work unofficially in, supposedly, 416, with publication following in 419, can thus be definitively rejected. La Bonnardière's proposals for the relative sequence of composition can still be accepted but her chronology for the later books must now be substantially revised, putting the composition of Books IX-XII some eight or nine years later than her estimate of AD 417-418. I must leave it to theologians to decide to what extent this new understanding of the chronology of the composition and completion of the later part of the De Trinitate affects our view of the development of Augustine's thought. I would note here only that it shows that the work's completion and publication was not a direct and immediate reaction to the condemnation of 
Pelagianism at the Council of Carthage in $418,{ }^{71}$ or to receiving the Sermo Arrianorum in 419, however much the need to combat Arianism and Pelagianism may have informed the work.

But the dating of completion and publication to 425-427 does bring into sharper focus the productiveness of the last five or six years of Augustine's life. The mid/late 420s were a period when Augustine was bringing to completion many long-running projects: the $D e$ Civitate Dei, begun in 413, was finished in 426; so too the De doctrina Christiana, begun $c$. 393, was also finished in 426. The completion of his third long-running project, the $D e$ Trinitate, thus falls precisely in this period, and this is hardly coincidence. The explanation may lie in Ep. 213, the record of the proceedings in the Basilica Pacis at Hippo on September $26^{\text {th }}, 426$, in which Augustine first designated the priest Eraclius as his successor as bishop after his decease; and then went on to transfer much of the daily business of his bishopric to Eraclius to leave himself time for theological research and writing:

But now I will assuredly begin to do, as the compassion of Christ may enable me, what I have not hitherto done. You know what for several years I would have done, had you permitted me. It was agreed between you and me that no one should intrude on me for five days of each week, that I might discharge the duty in the study of Scripture which my brethren and fathers the co-bishops were pleased to assign to me in the two councils of Numidia and Carthage. The agreement was duly recorded, you gave your consent, you signified it by acclamations. The record of your consent and of your acclamations, was read aloud to you. For a short time the agreement was observed by you; afterwards, it was violated without consideration, and I am not permitted to have leisure for the work which I wish to do: forenoon and afternoon alike, I am involved in the affairs of other people demanding my attention. I now beseech you, and solemnly engage you, for Christ's sake, to suffer me to devolve the burden of this part of my labours on this young man, I mean on Eraclius, the presbyter, whom today I designate in the name of Christ as my successor in the office of bishop.

The people shouted, saying twenty-six times, 'We give thanks for your decision.' 72

The Retractationes (427-428), a considered retrospect which required the re-reading of all his published works, are also evidently a product of this greater leisure time to think and write. It is very likely that what enabled the completion of at least some of the major works that had

\footnotetext{
${ }^{71} \mathrm{Cf}$. Plagnieux, 'L'influence de la lutte antipélagienne sur le De Trinitate', who thought that most of the De Trinitate was written relatively early on, and that it is only the later additions that show signs of the Pelagian controversy.

${ }^{72}$ Ep. 123, trans. J. G. Cunningham in Schaff, Pilkington, and Cunningham, The Confessions and Letters of St. Augustin, with a Sketch of his Life and Work.
} 
been so long in gestation - the De Civitate Dei, the De doctrina Christiana, and the De Trinitate — was the 'research leave' that Augustine negotiated for himself with his congregation at Hippo in September 426, freeing himself from administrative duties. Any modern academic will understand.

\section{Acknowledgements}

This paper owes its existence to Mary Carruthers, for it was in the course of trying to answer a question from her about how to translate a passage in De Trinitate Book IX in which Augustine recalls an arch at Carthage that my eye fell upon his mention of the moenia of Carthage a few lines earlier; and that sent me down the rabbit hole of Augustinian chronology. I am grateful to Philip Nothaft for helpful references on the date of Easter in the fifth century; and to Bryan Ward-Perkins and Neil McLynn for discussion on the use of the term moenia in late antiquity. 